\title{
HOW TO DEAL WITH THE VERSES OF WAR: Abdullah Saeed's Instructional Values on Reading the Qur'an
}

\author{
Akhmad Siddiq \\ Universitas Islam Negeri (UIN) Sunan Ampel Surabaya \\ Email: a.siddiq@uinsby.ac.id
}

\begin{abstract}
The connection between violence and religious principle from time to time has been an essential topic discussed among Muslim scholars. Many radical movements, such as the Islamic State of Iraq and Syiria (ISIS), referred to the Qur'an and hadith for justifying or rationalizing their violent acts. They consumed the verses of the Qur'an in order to graps and spread their mission. They hijacked the scripture in their behalf. This article aims to describe the verses of war in the Qur'an which structurally consists of social and political nuances. This article also discusses what so-called "permissive-structure" or "instruction-structure" and elucidates several verses of war, based on Tafsīr al-Qur'ān al-'Az̄īm written by Imam al-Ḥāfiz Abū al-Fidā' and alMīzān fī Tafsīr al-Qur'ān written by Sayyid Muhammad Ḥusayn alṬabātabā'̄̄. Using hermeneutical approach and discourse-analysis, this study argues that the verses of war in the Qur'an have been contextually misinterpreted by the radical groups to achieve their political interests.
\end{abstract}

Keywords: verses of war, instructional value, radicalism, contextualist interpretation.

DOI: http://dx.doi.org/10.20414/ujis.v25i1.423

\section{Introduction}

MUSLIMS perceive that the Qur'an is the foundation text of the Islamic law, besides hadith, $i j m \bar{a}^{\prime}$ (the consensus of the ulama) and qiyās (analogy). They have been preferring their religious practices to the Qur'anic values and instructions. In his book, Introduction to the Qur'an: History, Interpretation and Approaches, Abdullah Saeed wrote, "As the holy scripture of Islam, it is the primary text from which Islamic ethics, law and practice are derived. Muslims believe it is the direct word of God. It represents not only doctrines and religious teachings but also a way of life for millions of 
people."1 Moreover, Muslims believe that the Qur'an is "alive". It can affect and influence daily activities of human, in many ways. Mahmoud Ayoub called this phenomenon as "quasi-human personality":

Although the Qur'an has taken on the form of and character of human speech, it remains in "its essence a celestial archetype free from the limitations of human sounds and letters." Because the Qur'an intersects the human plane of existence and the transcendent word of the God, it is imbued with this quasi-human personality, imbued with feelings and emotions, ready even to contend on the Day of Resurrection with those who abandoned it in this life and to intercede for those who have lived by its teachings. ${ }^{2}$

Referring to Wilfred Cantwell Smith, in his book What is Scripture: A Comparative Approach, the Qur'an for Muslims is likely Christ for Christians. The Qur'an has a centrality in the main course of Islamic norms and practices. ${ }^{3}$ To some extents, Muslims were intended to create strong relation between the Qur'an and the Prophet Muhammad. 'Aishah - the Prophet's wife-once said that the attitude of the Prophet Muhammad is the Qur'an itself (kāna khuluquhu al-Qur'ān). This statement is to show inseparable nexus between the Qur'an and the hadith, the Prophet's saying.

Van der Leeuw, the German anthropologist, said that Islam is pre-eminently a religion of the book. ${ }^{4}$ Any readers of the history of Islam will richly find evidences that the Qur'an has had an important role on building Islamic civilization. In line with this, Nasr Hāmid Abū Zayd said that Islam is "a civilization of the text" (hadārah al-naș). ${ }^{5}$ Having this phenomenon, theologically and phenomenologically, it is difficult for Muslims to exclude certain

1 Abdullah Saeed, Introduction to the Qur'an: History, Interpretation and Approaches (New York: Routledge, 2008), xv.

${ }^{2}$ Mahmoud Ayoub, "Qur'an", in Encyclopedia of Religion, 176 in Farid Esack, The Qur'an: A Short Introduction (Oxford: Oneworld, 2002), 17.

3 Wilfred Cantwell Smith, What Is Scripture: A Comparative Approach (Minneapolis: Fortress Press, 1993), 46.

4 G. van der Leeuw, Religion in Essence and Manifestation (Princeton: Princeton University Press, 1986).

${ }^{5}$ See some works of Nasr Hāamid on reading and interpreting the Qur'an, such as Mafhum al-Naṣ Dirāsah fì 'Ulūm al-Qur'ān, Naqd al-Khițab al-Dīnī; Al-Ittijāh al-'Aqlī fì al-Tafsīr, Falsafat al-Ta'wīl, Isykāliyat al-Qirā'ah wa 'Aliyāt al-Ta'wīl, and so forth. 
verses of the Qur'an, because it will create any prejudice and edict claiming that he/she distrust the Qur'an as the basic principle. Muslims should consider that everything in the Qur'an is true, even it is visibly opposite or contrary with the logic of modern humanity.

In this context, some dilemmas may appear. Just to mention a few of examples, when modern culture tends to eliminate all violent concerns, there are some verses in the Qur'an that deal, and apparently support, violence. Without knowing and taking asbāb al-nuz $\bar{u} l$ (the background of the verses), someone will easily comprehend that the spirit of the Qur'an clash with spirit of modernity and humanity. To explain and avoid misunderstanding on interpreting the Qur'anic verses that involve violence, this article will describe several verses in the Qur'an that explicitly order Muslims to fight other believers. These verses clearly command Muslims to fight and attack others and commit violence to them. There are at least twelve verses in the Qur'an that instruct Muslims to make war, using the Arabic imperative word qātilu that means do fight. Among them are: al-Baqarah (190-193), alTawbah (29, 36, and 123), and al-Ḥujurāt (9).

There are approximately 170 verses in the Qur'an that are derived from Arabic word qa-ta-la which basically means "kill". This basic word could derive into several worlds such as qitāl (warfare), qatl (murder), uqtul (kill: imperative), qātilū (make war or fight against), and so forth. This paper focuses on a certain word, qātilū, to differentiate between murder and war, since the latter is more structurally social and political. It also discusses whether these verses belong to the "permissive-structure" or "instruction-structure" classification.

In his article, A Peaceful Message beyond the Permission of Warfare (Jihad), Sahiron Syamsuddin persisted that "the central message of these verses where permission for war was revealed for the first time is not that of war in or of itself. Instead it contains a message that upholds strong moral and ethical values..." 6 Syamsuddin is

6 Syamsuddin Sahiron, "A Peaceful Message beyond the Permission of Warfare (Jihad)"," in (Un)Common Sounds: Song of Peace and Reconciliation among 
aware that the focus of the Qur'anic message directs into morality and ethics, far away from violence and spirit of war. However, we could not overlook that the words used in the Qur'an are clearly imperative words. It means that the Qur'an ordered Muslims to make war and fight (qātil $\bar{u})$. To interpret these verses, I suppose, we better refer to Fazlur Rahman's idea of "double movement": linking a background of the verses with spirit of modernity in our times. $^{7}$

According to Abdullah Saeed, Rahman has advocated what is called "proto-contextualist" interpretation which is done by the Companions of the Prophet in early Islamic history. Saeed wrote, "His contribution to the development of an alternative methodology of interpretation of the ethico-legal texts in the Qur'an seeks to relate the text to its context, both of the revelation and of the Muslims of today." 8

Saeed insisted that the contextualist approach is needed to interpret the Qur'an because of mutability of the Qur'anic messages depending on the specific time and place. In his article, "Interpretation and Mutability: Socio-legal Texts of the Qur'an; Three Accounts from Contemporary Iran", Saeed discussed three prominent Iranian intellectuals regarding the contingent nature of the Qur'an's socio-legal passages. ${ }^{9}$

Saeed's contribution to Rahman's concept is evident in how the former understands and implements the contextual values of the Qur'an within contemporary discourses of Islamic thoughts. Saeed eventually constructed the four levels of interpretation: encounter with the world of text, critical analysis, meaning for the

Muslims and Christians, by Roberta N King and Sooi Ling Tan (Oregon: Cascade Books, 2014), 112.

7 Fazlur Rahman, Islam and Modernity: Transformation of an Intellectual Tradition (Chicago: University of Chicago Press, 1984); Fazlur Rahman, Major Themes of the Qur'an (Chicago: Bibliotheca Islamica, 1994).

${ }^{8}$ Abdullah Saeed, Interpreting the Qur'an: Towards a Contemporary Approach (New York: Routledge, 2006), 127.

${ }^{9}$ Abdullah Saeed and Ali Akbar, "Interpretation and Mutability: Socio-Legal Texts of the Quran; Three Accounts from Contemporary Iran," Middle Eastern Studies 54, no. 3 (May 2018): 442-458. 
first recipients, and meaning for the present. This hierarchical model bridges the context of the past with the present context. ${ }^{10}$

However, Mustofa reminds this interpretation model to not taking the context over the meaning of the text because, according to him, the glorification of the context could obscure the basic message of the text. This eventually will drive to construct what is called "local interpretation", "old and new interpretations", "local Islam", "Indonesian Islam", "Arabic Islam”, and so on. ${ }^{11}$

To discuss the verses of war in the Qur'an through Saeed's model of interpretation, this paper will firstly summarize his concept concerning hierarchical values in the Qur'an. The discussion will also mention Syamsudin's idea of "permissivestructure" and "instruction-structure" as an analytical tool to enrich perspectives in term of Indonesian context. Secondly, this paper will explore several verses relating to verses of war in the Qur'an, referring to both classical and modern books, suach as Tafsìr al-Qur'ān al-'Azīm, written by Imam al-Hāfiz Abū al-Fidā' Ismā'îl ibn 'Umar ibn Kathīr al-Dimashqi ${ }^{12}$ and al-Mìzān fì Tafsìr alQur'ān, written by Sayyid Muḥammad Ḥusayn al-Ṭabāțabā'î. Afterward, this paper will elucidate those verses using Abdullah Saeed's idea of the contextualist approach linked with current phenomenon of radicalism and interfaith relation.

\section{Hierarchical Nature of the Qur'anic Values}

Supporting the work of Fazlur Rahman, Abdullah Saeed attempted to identify and classify hierarchy of the Qur'anic values based on his understanding and interpretation on "right action". Saeed realizes that it is not easy because the notion of this term in the Qur'an is fluid. He attempted to "provide an extensive list of

${ }^{10}$ Read Lien Iffa Naf'atu, "Interpretasi Kontestual Abdullah Saed: Sebuah Penyempurnaan Terhadap Gagasan Tafsir Fazlur Rahman," Hermeneutik 9, no. 1 (June 2015): 65-90.

11 Imron Mustofa, "Kritik Metode Kontekstualisasi Penafsiran Al-Qur'an Abdullah Saeed," ISLAMICA: Jurnal Studi Keislaman 10, no. 2 (March 2016): 465491.

${ }^{12}$ Imam ibn Kathīr (701-774 H) is a very famous Muslim Commentator (of the Qur'an). He is a prolific intellectual that wrote many books on many discipline. Among them are al-Bidāyah wa al-Nihāyah, Jāmi' al-Masānid wa al-Sunan, Ikhtișar 'Ulūm al-Hadīth, Tabaqāt al-Syāfi'iyah, etc. 
values that can be classified and prioritized in order to arrive at some form of hierarchy that reflects the Qur'anic emphasis." 13 In the end, Saeed concluded the following categories as hierarchical values in the Qur'an: obligatory, fundamental, protectional, implementational, and instructional. In doing this categorization, he considered several basic principles of Islam, such as essential belief of Islam, six pillars of faiths, and clear prohibition and permission in the Qur'an. ${ }^{14}$

The first is obligatory values. To explain this category, Saeed needs to make at least three sub-categories: (1), values related to the system of belief (immann); (2) values related to devotional practices emphasized in the Qur'an, such as prayer, fasting, and pilgrimage (Islām); (3) clear and unambiguous prohibition and permission. Just to give an example of the third sub-category, here is two verses of the Qur'an mentioned by Saeed:

"It is made lawful to you to go into your wives on the night of the fast." ${ }^{15}$

"And the divorced women should keep themselves in waiting for three courses; and it is not lawful for them that they should conceal what God has created in their wombs, if they believe in God and the last day."16

The second is fundamental values. These values are perceived as "human" values that relate to protection of human's life, family, or property. Referring to some Islamic discourse of the consensus (ijma $\left.\bar{a}^{\prime}\right)$ and public interest (mașlahah), Saeed persisted that most of Islamic principles are constructed by recognizing universal values: humanism. He remarks human rights as universal values were also pondered in the Qur'an.

The third is protectional values. It represents as practical legislation for the previous values (fundamental). To elucidate this category, Saeed wrote:

For instance, protection of property is a fundamental value but that value has no meaning unless put into practice. This can be done not by merely stating the value but also by requiring a means of 'protecting' that value, by prohibiting theft or riba. While a fundamental value does not depend on just one 'proof' (text) for its validity, the protectional value often depends on one

\footnotetext{
13 Ibid., 129.

${ }^{14}$ Ibid., 130.

${ }^{15}$ Qs. al-Baqarah: 187.

${ }^{16}$ Qs. al-Baqarah: 228.
} 
or a few 'textual proof'. This does not reduce the importance given to it in the Qur'an, since the strength of the protectional value is largely derived from the fundamental value and the specific command relating to the protectional value itself. Since protectional values are essential to the maintenance of fundamental values, universality is also extended to the protectional value. ${ }^{17}$

The fourth is implementational values. This category is the following stage of protectional values. It means that to implement protectional values, we need some more practical verses which directly point out the case. Saeed gave example of the case of thief and zinā (unlawful sexual intercourse), but might not necessary to explore here. To sum up, Saeed believes that "considerations such as these led to the enormous increase in conditions set out by jurists for the implementation of hadd punishments like amputation, flogging and stoning." 18

The fifth is instructional values. On one hand, Saeed has implicitly seen this value to be more open for contextualizing the Qur'an. He explains this category as values taken "in relation to a problem quite specific to circumstances at the time of the revelation." On the other hand, he warned of emergence of problematic dilemma which could be faced by Muslim commentators. He mentioned several cases, such as instruction to marry more than one woman in certain circumstances, instruction to be good to specified people, and instruction not to take unbelievers as 'friends'.

Another example is paradigmatic and theological change which appeared before and after revelation of surah al-Tawbah. Saeed described that before surah al-Tawbah, "Jews, Christians and idolaters were all able to retain their religions without intervention as long as they did not engage in hostile activity against Muslims. This situation appears to have changed in Year 9/630 with the revelation of al-Tawbah." After the revelation of alTawbah, Muslims were ordered to resist and fight against all the idolaters unless they accepted Islam. Similarly, Muslims will also fight against the People of the Book who did not believe in Islam, until they paid the jizyah (tax).

${ }^{17}$ Saeed, Interpreting the Qur'an, 134.

${ }^{18}$ Ibid., 136. 
In the process of interpretation, hermeneutical conception of Abdullah Saeed is very critical to emphasize that verses of the Qur'an come with varied structures and different contexts. To interpret and implement values of the Qur'an, someone has to practice Rahman's idea of "double movement", since textual approach will only drive readers and interpreters toward ahistorical understanding. The meanings of the Qur'an is not static: it is changing, contextual, and contextualized. It is stated that the Qur'an is șăliḥ li kulli makān wa zamān: being adaptively compatible wherever and whenever. ${ }^{19}$ To interpret the Qur'an, someone should not be "drawing mainly on linguistic rather than social or historical analysis." 20 Underlining contextual approach on understanding and interpreting the Qur'an, Saeed insisted that it is impossible to get true objective meaning of the Qur'an. Each interpretation is dependent on certain experiences, values, beliefs and presuppositions. ${ }^{21}$

\section{Interpreting Call for War in the Qur'an}

In the following, I will depict several verses in the Qur'an that give clear command for Muslims to fight against non-Muslims (idolaters) at the era of the Prophet. These verses are chosen to represent an explicit command from the Qur'an using a certain word of qātilu (to fight against or to combat). Here I refer to both classical and modern books. The first is Tafsìr al-Qur'ān al-'Azīm, written by Imām al-Hāfiz Abū al-Fidā' Ismā'îl ibn 'Umar ibn Kathīr al-Dimashqi. The second is al-Mìzān fì Tafsìr al-Qur'ān, written by Sayyid Muhammad Ḥusayn al-Ṭabāṭabā'̂. ${ }^{22}$ Why do we choose Ibn Kathīr and al-Ṭabătabā'î? This choice was based on two considerations. Firstly, Tafsīr Ibn Kathīr represents a mainstream interpretation of Muslim, especially traditional, scholars. Among the Sunni Muslim, it become one of the highest references to

19 'Abdurrahmān Ḥamd 'Alī Imrān, Dìn al-Haqq (KSA: Ministry of Islamic Affairs, 1998), 79-80; Read also Jalāl al-Dīn 'Abd al-Raḥmān ibn Abī Bakr AlSuyūṭì, Al-Itqān fì 'Ulūm al-Qur'ān (Beirut: Dār al-Kutub al-'Ilmiyah, 2003).

${ }^{20}$ Saeed, Introduction to the Qur'an, 220.

${ }^{21}$ Ibid., 221.

${ }^{22}$ He was born in Tabriz (1892) and grew within honorable and intellectual family. He was died in Qum (1981). 
discuss the Qur'an, its meaning and interpretation. In contrary, alMìzān fì Tafsìr al-Qur'ān represents the interpretation of the Qur'an written by Shiite Muslim scholar. Imam al-Ṭabātabā'̄ is one of the leading Shiite intellectuals in the Islamic Republic of Iran. Secondly, it represents a classical period of Islamic discourse. Written in the thirteenth century, I assume, this book gives theologically and linguistically different logic compared with other books in the current times. Unlike Tafsìr Ibn Kathìr, al-Mīzān $f_{\imath}$ Tafsìr al-Qur'ān gives us more perspectives on interpreting the Qur'an, sociologically, politically, linguistically, and historically.

Here are some of the Qur'anic verses concerning war and violence:

Qs. al-Baqarah: 190-193

"Fight in the cause of Allah those who fight you, but do not transgress limits; for Allah loveth not transgressors. (190) And slay them wherever ye catch them, and turn them out from where they have Turned you out; for tumult and oppression are worse than slaughter; but fight them not at the Sacred Mosque, unless they (first) fight you there; but if they fight you, slay them. Such is the reward of those who suppress faith. (191) But if they cease, Allah is Oft-forgiving, Most Merciful. (192) And fight them on until there is no more Tumult or oppression, and there prevail justice and faith in Allah. but if they cease, Let there be no hostility except to those who practise oppression. (193)." 23

Ibn Kathīr explains that this verse was the first war-verse revealed in Medina. It was revealed at the time when the Prophet Muhammad has never conducting a war only for those who attack the Muslim people in Medina. It happens until the verses of alTawbah revealed which command Muslims to fight against polytheists wherever they meet. Some ulama said that this latter abrogated all previous verses, including these verses of alBaqarah: 190-193. Ibn Kathīr also describes that it is kind of revenge for the Muslims. The word "And slay them wherever ye catch them, and turn them out from where they have Turned you out" means to increase Muslim spirit to kill them as well as they killed

${ }^{23}$ All translation in this paper referred to Abdullah Yusuf Ali, The Holy Qur'an (Hertfordshire: Wordsworth Classics, 2000). 
Muslims before, to drive them out from Mecca as well as they drove the Muslims out before. ${ }^{24}$

It is worth noting that these verses give limitations, conditional restrictions. First is not to overstep on killing others. Ibn Kathīr denotes that the Prophet Muhammad commonly gives a speech before war and says, "Go away in the name of Allah, fight in the path of Allah, against all people who unbelieve Allah, but do not overstep, do not violet, do not mutilate, and do not kill children and the priests." 25 In this regard, Ibn Kathīr also mentions several hadith concerning this ethical guidance of war. Second is to relocate the war outside al-Haram Mosque. "But fight them not at the Sacred Mosque, unless they (first) fight you there." 26

In al-Mìzān fì Tafsīr al-Qur'ān, al-Țabāțabā'ì merges the six verses of al-Baqarah (190-196) and perceives that these verses revealed in one time. He explains that these verses are revealed to face polytheists and idolaters of Mecca. In line with Ibn Kathīr, alTabāțabā'ī stresses on reprisal nuances on these verses: qișās. It is clear that the object of these verses was those who live in Mecca from several terms: al-fitna, driving out, qișāṣ, and al-Haram Mosque. ${ }^{27}$

Exploring the verse "And fight them on until there is no more Tumult or oppression, and there prevail justice and faith in Allah", alTabātabā'ì reminds us the story of polytheist's slander to the Prophet and his Companions in Mecca, before the hijra. It means that Muslims must take the power from the people of Mecca and make Islam as religion of Allah although this must be done after call for Islam ( $\left.d a^{\prime} w a h\right)$. Al-Ṭabātabā'ì emphasizes that these verses were revealed in a certain context, to certain object for certain subject with certain case. Implicitly, I assume, he aims to state that these verses have its own context.

After connecting these verses with other verses of war in different part of the Qur'an, al-Tabāțabā'ì concludes that Islam is

${ }^{24}$ Al-Imām Abū al-Fidā' Ismā'îl ibn 'Umar Ibn Kathīr, Tafsīr al-Qur'ān alAžìm (Beirut: Dār al-Kutub al-`Ilmiyah, 1998), 387.

${ }^{25}$ Al-Musnad, vol 1, 300.

${ }^{26}$ Qs. Al-Baqarah: 191.

27 Sayyid Muhammad Ḥusayn al-Ṭabāṭabā'ī, Al-Mīzān fì Tafsīr al-Qur'ān (Beirut: Mu’āssasah al-A'lā, 1991), 60. 
the religion of tawhìd, that is, based on humanity. He emphasizes what God said, "So set thou thy face steadily and truly to the Faith: (establish) Allah's handiwork according to the pattern on which He has made mankind: no change (let there be) in the work (wrought) by Allah. That is the standard religion, but most among mankind understand not." 28 According to him, Muslims have to fight to defend their religion, because it will keep religion stable and continuous. According to al-Ṭabāțabā'ì, every war should be a defense for humanity (difä' 'an haqqu al-insāniyya). ${ }^{29}$

I will stand with Ṭabāțabā'i arguing that war in Islam is not a defense for religious identity, namely Islam, but a defense for encouraging humanity (human rights). The Prophet Muhammad have once given a standing appreciation for a Jewish corpse carried in front of him. The Prophet taught his companions to respect someone based on humanity rather than his/her religiosity. ${ }^{30}$ Referring to what Gamal Albanna said in the gender discourse, "al-insān awwalan wa al-unthā thāniyan" (humanity first before femininity). ${ }^{31}$ It is an ethical nature of Islam, as Ibn Kathīr underlined, not to strengthen devastating war.

Qs. al-Tawbah: 29

"Fight those who believe not in Allah nor the Last Day, nor hold that forbidden which hath been forbidden by Allah and His Messenger, nor acknowledge the religion of Truth, (even if they are) of the People of the Book, until they pay the Jizya with willing submission, and feel themselves subdued."

This verse is a consequential action after judging that polytheists are unclean (najs). The previous verse clearly said, "O ye who believe! Truly the Pagans are unclean; so let them not, after this year of theirs, approach the Sacred Mosque. And if ye fear poverty, soon will Allah enrich you, if He wills, out of His bounty, for Allah is All-knowing, All-wise." 32 Ibn Kathīr highlights that the

\footnotetext{
${ }^{28}$ Qs. al-Rūm: 30.

${ }^{29}$ al-Ṭabātabā'ì', al-Mìzān, 67.

${ }^{30}$ Hadith of Bukhari, no. 1311.

${ }^{31}$ Read Gamal Albanna, al-Mar'ah al-Muslimah baina Tahrīr al-Qur'ān wa Taqyīd al-Fuqahā' (Cairo: Dār al-Fikr al-Islāmī, 1998).

${ }^{32}$ Qs. al-Tawbah: 28.
} 
meaning of unclean here is religious claim. ${ }^{33}$ They will never come to the al-Haram Mosque after the seventh year of hijra. It was noted that the Prophet commended 'Alī ibn Abī Tālib and Abū Bakr to announce this prohibition to the pagans. The Prophet said, "Polytheist will never enter this Mosque (al-Haram Mosque) after this year, unless who has been involved in pledge or slavery." 34

Ibn Kathīr states that this verse is the first verse calling for killing and combating the people of the book (ahl al-kitāb), after many years where Muslims are only fighting against the pagans. Eventually, the Prophet invited all people around Medina to join and make a strong army to fight against the Roman Empire. This mission continued until the era of Caliphate 'Umar ibn Khațāb, the first Muslim leader that succeed to reach Roman Empire. ${ }^{35}$

Unlike Ibn Kathīr who merges this verse with the previous verse, al-Tabāțabā'i merges it with the following verses of 31-35. It is kind of different perspective on classifying and interpreting verses. Al-Ṭabāțabā'i emphasizes more on what is infidelity and the consequences of it, while Ibn Kathīr focuses more on the call for war in the verse. Al-Ṭabāțabā'i explains that "the people of the book" point out Jews, Christians, and Zoroastrian (Magians). ${ }^{36} \mathrm{He}$ supports his argument by citing the verse, "Those who believe (in the Qur'an), those who follow the Jewish (scriptures), and the Sabians, Christians, Magians, and Polytheists, Allah will judge between them on the Day of Judgment: for Allah is witness of all things." ${ }^{37}$ In this regard, al-Ṭabātabā'î puts all non-Muslims in the same spot of kufr (infidelity). He argued that they were infidels because of their rejection and denial on the prophecy of Muhammad. If the pagans developed their infidelity with their rejection for tawhid (monotheism), the people of the book obtained their infidelity with their denial of prophecy of the Prophet Muhammad. ${ }^{38}$

\footnotetext{
${ }^{33} \mathrm{Ibn}$ Kathīr, Tafsīr al-Qur'ān al-Azìm, vol. 2, 115.

34 Ibid., 115.

${ }^{35}$ Ibid., 117.

${ }^{36}$ al-Ṭabāṭabā'ī, al-Mìzān, 244.

${ }^{37}$ Qs. Al-Hajj, 17.

${ }^{38}$ al-Ṭabāṭabā'ī, al-Mīzān, vol. 6, 246.
} 
At a glance, this verse seems to allow violence and war in the name of religion, but it will be clearly disputed by contextualizing it with the political tension between the Arab (Muslim) and the Roman Empire (Christian) at the time. The verse pointed out the people of the book who have politically challenged Arab community and the Persian in the (Middle) East.

Qs. al-Tawbah: 36

"The number of months in the sight of Allah is twelve (in a year)- so ordained by Him the day He created the heavens and the earth; of them four are sacred: that is the straight usage. So wrong not yourselves therein, and fight the Pagans all together as they fight you all together. But know that Allah is with those who restrain themselves."

Interpreting this verse, Ibn Kathīr starts with questioning what is "of them four are sacred". He quotes several hadith talking about this months, and persists that these months are Dhulqa'dah, Dhulhijjah, Muharram, and Rajab. ${ }^{39}$ Moreover, he is also questioning whether this verse was abrogated by another verse or not, because the history noted that within these "sacred months", the Prophet besieged the people of Taif, namely in Dhulqa'dah. However, another perspective persisted that it is unlawful to conduct war within these months. Allah said, "O ye who believe! Violate not the sanctity of the symbols of Allah, nor of the sacred month." 40

From the very beginning al-Ṭabātabā'î persists that the purpose of these months is qamariyya (lunar) calendar which is based on rotation of the moon, not shamsiyya (solar) calendar. Firstly, he argued, it because God mentioned the "sacred months" which are only renowned in the Islamic calendar, and secondly because of the term "in the sight of Allah" that points out consistency and unchanged times: and it is only involved in qamariyya calendar, according to him because shamsiyya calender was human-creation. ${ }^{11}$

This verse, al-Ṭabātabā'î wrote, only reveal to polytheists, the pagans, and not the people of the book. Although, in some cases,

\footnotetext{
${ }^{39}$ Ibn Kathīr, Tafsìr al-Qur'ān al-Azìm, vol. 4, 127.

${ }^{40}$ Qs. al-Mā'idah: 2.

${ }^{41}$ al-Ṭabāțabā'ī, al-Mīzān, vol. 6, 276-277.
} 
kufr could be pointed out to the people of the book, but the main aim of "the Pagans" (al-mushrikūn) is clearly polytheists/idolaters. ${ }^{42}$ It is interesting to note that this verse, according to al-Ṭabāțabā'ī, did not abrogate other verses on taking jizya (paying tax) from the people of the book. It means that this verse has its own context and specific cause.

The verse gives time limitations of having war based on Arab culture which respects several "sacred" months in a year. It means that war at the time has been rooted in more political and social manner than religious and spiritual matter. If this limitation was based on religion, it will not recognize time since religion has no applicability with month. Indeed, religion, namely Islam, acknowledges these months as sacred times to urge people avoiding violence and eluding war.

Qs. al-Tawbah: 123

"O ye who believe! fight the unbelievers who gird you about, and let them find firmness in you: and know that Allah is with those who fear Him."

This verse, Ibn Kathīr wrote, commanded Muslims to fight against all unbelievers, step by step. It is a gradual movement to clear the Arab Peninsula from them. At the beginning, the Prophet started with combating the pagans by conquering Mecca, Medina, Țā'if, Yemen, and other places in the Peninsula. When many people believed in Islam and created a community of Muslim, the Prophet began to strike and invite the people of the book to Islam. The closer destination at the time is the Roman Empire. ${ }^{43}$ It is to show that Islam could be a leading government that will properly serve human needs based on the divine guidance.

In line with Ibn Kathīr, al-Ṭabāțabā'ì sees this verse as a common call for Muslims to fight against all unbelievers to show them dignity of Islam and rightness of Islamic doctrine. It will only be extended by governing the world and serving humanity in a holistic way. ${ }^{4}$

\footnotetext{
${ }^{42}$ Ibid., vol. 6, 279.

${ }^{43} \mathrm{Ibn}$ Kathīr, Tafsìr al-Qur'ān al-Ażìm, vol. 4, 208.

${ }^{44}$ al-Ṭabāṭabā'î̀, al-Mìzān, vol. 6, 419.
} 
"And let them find firmness in you." Ibn Kathīr interpreted this verse by insisting that Muslims should be "soft" toward other Muslims, but they must be "tough" toward unbelievers. ${ }^{45} \mathrm{Al}-$ Tabătabā'i explores more about this verse and said that the meaning of "firmness" here is not "violence", "bad attitude", "rigidity", "roughness", and the like. Surely, every religious teaching condemned these negative favors. ${ }^{46}$ The purpose of it is to be moderate and pious. "And know that Allah is with those who fear Him."

Qs. al-Hujurät: 9.

"If two parties among the Believers fall into a quarrel, make ye peace between them: but if one of them transgresses beyond bounds against the other then fight ye (all) against the one that transgresses until it complies with the command of Allah; but if it complies then make peace between them with justice and be fair: for Allah loves those who are fair (and just)."

Unlike the previous verses that discuss fighting against nonMuslim believers, this verse concerns about advocating the Muslim group which is involved in conflict with another Muslim group. The Qur'an ordered Muslims to support reconciliation between the two groups. But if one of them insists not to reconcile and resolve the conflict, this verse commanded Muslims to fight against the stubborn group, until they comply with the command of Allah. As explained before, the word qātilu means the battle between two groups or more, not only killing and slaying.

Ibn Kathīr justifies that this verse ordered Muslims to build peaceful intra-religious relationship between Muslims and their fellow Muslims. In doing so, when two groups of Muslims were involved in certain conflict, other Muslims should mediate them. In the theory of conflict reconciliation, should be there a third party attempting to mediate and intervene for making peace. ${ }^{47}$ According to the majority of Muslim intellectual, the group who

${ }^{45}$ Ibn Kathīr, Tafsīr al-Qur'ān al-Aẓìm, vol. 4, 209.

46 al-Ṭabāṭabā'î̀, al-Mīzān, vol. 6, 419.

47 For further reading read I William Zartman, Negotiation and Conflict Management (New York: Routledge, 2008); Stewart Levine, Getting to Resolution: Turning Conflict into Collaboration (California: Berret-Koehler Publisher, 2009); Michael J. Butler, International Conflict Management (New York: Routledge, 2009). 
did "wrong action" (ma'siyah) is still perceived as Muslim with disregard. Only Khawārij and Muktazila that perceive such group as turning out of Islam. However, Ibn Kathīr reminds us that this fight in this context is a process of warning, guiding, and giving advice amongst Muslims, not to harm and hurt them. ${ }^{48}$ The main focus is to resolve not to make a war.

Al-Tabātabā'ì's interpretation is apparently in line with that of Ibn Kathīr concerning the verse. He warns us to be fair on advocating or eliminating certain group. God said, "with justice and be fair." 49 Al-Ṭabāțabā'i links this verse with the following verse that persists on brotherhood among Muslims and believers. "The Believers are but a single Brotherhood: So make peace and reconciliation between your two (contending) brothers; and fear Allah, that ye may receive Mercy." 50

This verse emphasizes on peacemaking and peacebuilding among Muslims. However, the spirit of conducting peaceful life should be practiced and implemented in the wider realm and larger context. The ethical guidance should not be limited only among Muslims, within intra-religious relationship, but also among non-Muslims, within inter-religious relationship.

\section{Contextualizing Peaceful Message of the Qur'an}

Referring to Schleiemacher, F. Budi Hardiman identified hermeneutics as an "art of understanding", kunstslehre des verstehens. In this context, he understands understanding as an endless process to seek meaning (verb), which is different with understanding as a product (nouns). In Germany, it differs between verstehen (verb) and verstandnis (nouns). ${ }^{51}$ Hardiman also emphasizes that to understand is not to interpret, although we have to understand to interpret. ${ }^{52}$ In this regard, I will discuss

${ }^{48}$ Ibn Kathīr, Tafsìr al-Qur'ān al-Aẓìm, vol. 7, 349.

${ }^{49}$ al-Ṭabāțabā'ì, al-Mìzzān, vol. 18, 319.

${ }^{50}$ Qs. al-Hujurāt: 10.

${ }^{51}$ F. Budi Hardiman, Seni Memahami Hermeneutik dari Schleiemacher sampai Derrida (Yogyakarta: Kanisius, 2015), 31; Read also Nicholas Davey, Unquiet Understanding: Gadamer's Philosophical Hermeneutics (New York: State University of New York Press, 2006), 38.

${ }^{52}$ Hardiman, Seni Memahami Hermeneutik, 21. 
some previous verses to understand, and eventually to interpret or reinterpret them, based on current philosophical and theological consideration. It is kind of contextualization and hermeneutical approach.

It is worth noting that all verses discussed here are based on the choice of the linguistic same-ness: one word, qätilü. This word is imperative form from the basic word of qätala which means "make war" (hāraba) or "defense" (dāfa'a). It differs from uqtulū, the other word used in the Qur'an to eliminate or slay people, which means "kill" or "diminish". ${ }^{53}$ It is to emphasize that the topic we are discussing is about relationship between one community and another community or one group to another group. War is non-personal case which requires very important rationale to decide. Probably, in the classical period war has become first choice to solve political or social problem, but in our times today it should be recognized as last choice (or non-choice) after diplomatic and persuasive approach.

Both of Tafsìr al-Qur'ān al-Karìm and al-Mìzān fì Tafsìr al-Qur'ān approved that all verses in this context were engaged within stateto-state (Mecca and Medina, for instance) or community-tocommunity (Muslims to other Muslims) relation. There are political and social nuance of war inside these verses. For instance, the term used in the verse "O ye who believe! fight the unbelievers who gird you about, and let them find firmness in you" signifies "animosity" between religious believers. There was a contestation between Muslims and non-Muslims, and each attempted to reach a governing power toward other. And the power, we noted, is one of the most important things in political domains. ${ }^{54}$

The first verse (al-Baqara: 190-193) implicitly elucidates power contestation between Muslims and non-Muslims. It was kind of retaliation. In this regard, politics become a keyword, being perceived as one of considerations besides theological, cultural, or

53 Shawqī Dayf et al., Al-Mu'jam al-Wasìt (Cairo: Majma' al-Lughah al'Arabiyah, 2004), 715.

54 John Locke, Two Treaties of Government (Cambridge: Cambridge University Press, 1960); Bridget Coggin, Power Politics and State Formation in the Twentieth Century: The Dynamics of Recognition (Cambridge: Cambridge University Press, 2014). 
economic manners. It is also known that in the history of early Islam, Muslims faced many tortures and suffers, namely from polytheists and the pagans of Mecca. It was period of constructing and building the Islamic foundation. They were afflicted and persecuted. The Prophet Muhammad had to find external assistance and support to back his companions up. He connected the King Negus in Abyssinia and asked him to give protection for his companions. While the condition became worst, the Prophet initiated to travel (hijra) to Medina. He decided to spread Islamic teaching in Medina (Yathrib) after his agreement with the people of Medina. ${ }^{55}$

Having his own authority to build a Muslim community in Medina, the Prophet Muhammad continuously expand and spread his teaching to the people surrounding Medina, including his "enemies" in Mecca. Some wars and battles happened between them because of political tension. This verse is involved within this political condition. The Conquest of Mecca in $8 \mathrm{H}(630 \mathrm{M})$ by Muslims should become bloodshed for revenge, but the Prophet did not make it. However, this verse demonstrated a deeply political nuance of doing war or fighting others.

It also indicated that each war, each battle, has its own political background. Each experienced its exceptional context. Every war in the history of Islam has been rooted in distinguished cases. The war of Badr differs from the war of Uhud, the war of Tabuk was different with the war of Bani Qainaqa, and so forth. And every verse in the Quran that speaks about war has its own contextual background. Actually, it has been long discussion among Muslim commentators and interpreters to hold between two basic principles of Qur'anic interpretation: between word (lafz) or cause (al-sabab). First principle says that al-'ibrah bi 'umūm al-lafz la bi khușuss al-sabab (consideration is based on the general word not on the specific cause), and the second states that al-ibrah bi khușūs al-sabab la bi 'umūm al-lafž (consideration is based on the

55 Read more Muhammad Husayn Haykal, Hayāt Muḥammad (Cairo: alHay'ah al-Miṣriyyah al-'Ammah li al-Kitab, 2001); 'Abd al-Mālik Ibn Hishām, AlSīrah al-Nabawiyyah (Cairo: Dār al-Hadīth, 1998); Musțafā al-Sibā'ì, Al-Sīrah alNabawiyyah Durūs wa 'Ibar (Cairo: Dār al-Salām, 1998). 
specific cause not on the general word). ${ }^{56}$ A contextualist interpretation will surely deliver the second principle that recognizes the cause as a basic consideration on understanding and interpreting the Qur'an. It is evidently declared by Abdullah Saeed, stating that "A contextualist interpretation of the Qur'an expects the interpreter to keep a close eye on the hierarchical nature of the values that they encounter in any Qur'anic text." 57

Strengthening the second position, Syamsuddin reminds us to distinguish between verses revealed in "permissive-structure" and other verses revealed in "instruction-structure". He emphasizes on universal values that are inherent in many verses of the Qur'an: ethically or theologically. He wrote after explaining some verses in this regard that "the central message of these verses where permission for war was revealed for the first time is not that of war in or of itself. Instead it contains a message that upholds strong moral and ethical value" ${ }^{58}$ To be permitted, according to him, does not mean to be instructed forever. And to be instructed in a certain period also does not mean to be instructed forever.

To counter the first position perceiving that al'ibrah bi 'umūm al-lafz la bi khușuṣ al-sabab, it should be noted that a general command to do war or jihad opens space for various interpretations. In other words, the Qur'an does not limit the interpretation to only one commentary. The Prophet's companion and his son-in-law, 'Alī ibn Abī Talib, said that the Qur'an is hammāl al-wujūh (multi-interpretative). In this context, the more general the word is, the more vary it could be interpreted. Look at, for instance, al-Anfāl: 39, "And fight them on until there is no more tumult or oppression, and there prevail justice and faith in Allah altogether and everywhere; but if they cease, verily Allah doth see all that they do." The editorial word here is general, but evidently it directs to certain historical cause behind the verse. Again, to understand spirit of the Qur'an, we should comprehend the context of historical verse and its context in our current times.

\footnotetext{
${ }^{56}$ For further reading see Muhammad Abū Shahbah, Al-Madkhal li Dirāsāt alQur'ān (Riyad-KSA: Dār al-Liwā, 1987).

57 Abdullah Saeed, Reading the Qur'an in the Twenty-First Century: A Contextualist Approach (New York: Routledge, 2014), 64.

${ }^{58}$ Sahiron, "A Peaceful," 112.
} 
In other perspective, the verse of Al-Hujurāt 9 intensely portrays how the Qur'an sees an internal problem between a Muslim group with another Muslim group. When there is a tension between two Muslim groups and they were engaged in war, other Muslims ought to be the third-party mediating and resolving the conflict. There are some lessons that can be taken from this verse, concerning conflict transformation. First, social conflict can emerge within the same religious believers. It means that the sameness of faith does not guarantee the sameness on perceiving and seeing other deeds. Economics, politics, and culture to some extents ruin sense of Islamic brotherhood ( $u k h u w a$ Islāmiyya). Religious affirmation sometimes has not been recognized as primary consideration. Flashing back to history of the early Islam, especially after Prophet Era, we will face some tension and war between a certain group and another within Muslim community. One of them was the tension between 'Alì ibn $A b \bar{i}$ TTalib and Mu'awiyya. It has historically influenced Muslim relationship until today, namely within the conflict between Sunni and Shiite community.

Second, emergence of the third-party is a must. To solve the problem among conflicting groups, we must build mediating processes to resolve and reconcile the conflict. Harmful persons cannot heal themselves. They need a "doctor". They need medicine. They need other perspective on looking at the conflict and overtaking it. But it is not easy to be the third party because in some cases, it requires several formal procedures. Within personal conflict, it may appear easily on positive and helpful initiative from person or organization. In a broader case, conflict of war, it will involve more complicated parties. Definitely, kind of this procedure has not been explained in the Qur'an. It will flow and follow contextual necessities. It differs from one space to another, from one nation to another, from one state to another. the question is: who deserves to be the third party? Who decides to determine the third party for mediating the conflict? This question appears in respond with inclusiveness of Qur'anic interpretation.

Third, the main concern of the Qur'an is peace-making, reconciliation, and peace-keeping. Essentially, war in the Qur'anic explanation toward historical approach at the time could be very 
different with our political and cultural approach in this time. To strengthen this position, we can see below several verses that maintain reconciliation and peace-building among society:

"They ask thee concerning (things taken as) spoils of war. Say: "(such) spoils are at the disposal of Allah and the Messenger. So fear Allah, and keep straight the relations between yourselves." 59

"The Believers are but a single Brotherhood: So make peace and reconciliation between your two (contending) brothers; and fear Allah, that ye may receive Mercy." 60

"If a wife fears cruelty or desertion on her husband's part, there is no blame on them if they arrange an amicable settlement between themselves; and such settlement is best." 61

\section{Conclusion}

Looking at the fact that the Qur'anic verses of war had been applied as justification for making violence and war, we could scrutinize Islamic State in Iraq and al-Sham (ISIS) movement in the Middle East as an illustration. On doing their brutality and horrible actions (e.g. burning alive, destroying tombs, reviving slavery, beheading, and crucifixion), ISIS religiously referred to the Qur' an and the hadith as the foundation text of Islam. In his thesis, The Islamic State in Iraq and al-Sham (ISIS): Anatomy of Theology and Justifications of Violence, Aziz Anwar Fahcrodin highlighted that ISIS used brutality and terror as their deterrent strategy based on religious-textual sources (mostly Qur'an and hadith). ${ }^{62}$ Just to mention a verse stipulated by ISIS to make violence, namely crucifixion, Aziz mentioned how ISIS used the Qur'an 5:3363 to legitimize their repulsive actions toward their opponents. ${ }^{64}$

${ }^{59}$ Qs. al-Anfāl: 1.

${ }^{60}$ Qs. al-Hujurāt: 10.

${ }^{61}$ Qs. al-Nisā': 128.

${ }^{62}$ Aziz Anwar Fahcrodin, The Islamic State in Ira and Al-Sham (ISIS): Anatomy of Theology and Justifications of Violence (Yogyakarta: Center for Religious and Cross-Cultural Studies, 2016), 95.

${ }^{63}$ The translation of the verse is: "Indeed, the penalty for those who wage war against Allah and His Messenger and strive upon earth [to cause] corruption is none but that they be killed or crucified or that their hands and feet be cut off from opposite sides or that they be exiled from the land. That is for them a disgrace in this world; and from them in the Hereafter is a great punishment."

${ }^{64}$ Fahcrodin, The Islamic State, 107. 
Realizing "instructional form" on the verses of war in the Qur'an, it is important to recognize historical context of the Qur'anic revelation and relate it with the current situation: religiously and politically. Referring to Syamsudin, we must clearly identify between the "permission" and "instruction" structure of message within the Qur'anic verses of war. Several verses mentioned in this paper, that order Muslim to fight and kill others (polytheists and the pagans), must be seen in its own (classical) context, on the one hand, and be interpreted with progressive-modern reading, on the other. The logic of war in the classical time differs from the logic of it in our times. Abdullah Saeed said, these verses keep instructional values that "refer to specific instructions, suggestions, advice, and exhortations in the Qur'an in relation to Particular issues, situations, circumstances, and contexts." 65 Indeed, contextual approach must be applied to link the authoritative text and the authentic context. In today context of Indonesia, it is precious that dissemination of inclusive interpretation toward religious text has been encouraged through seminars, social media, newspaper, journals, and other academic events. ${ }^{66}$ It is an effort to make Indonesian future brighter and peacefully smarter.

\section{References}

Ali, Abdullah Yusuf. The Holy Qur'an. Hertfordshire: Wordsworth Classics, 2000.

Al-Suyūṭ̂i, Jalāl al-Dīn 'Abd al-Raḥmān ibn Abī Bakr. Al-Itqān fì 'Ulūm al-Qur'ān. Beirut: Dār al-Kutub al-'Ilmiyah, 2003.

Butler, Michael J. International Conflict Management. New York: Routledge, 2009.

Coggin, Bridget. Power Politics and State Formation in the Twentieth

Century: The Dynamics of Recognition. Cambridge: Cambridge

${ }^{65}$ Saeed, Reading the Qur'an, 68.

${ }^{66}$ BNPT (Indonesian National Agency for Combating Terrorism) conducted many activisms to reduce and eliminate radical ideas among Indonesia people. The Agency held seminars and lectures in universities and gave trainings or elucidations through religious organization, that is, to promote moderate approach and inclusive interpretation toward religious text. See its official website on https://www.bnpt.go.id/. 
University Press, 2014.

Davey, Nicholas. Unquiet Understanding: Gadamer's Philosophical Hermeneutics. New York: State University of New York Press, 2006.

Ḍayf, Shawqīe Ḥāmid 'Abd al-Qādir, Muhammad 'Alī al-Najjar Ibrāhīm Musṭafā, and Aḥmad Ḥasan al-Zayyat. Al-Mu'jam alWasit. Cairo: Majma' al-Lughah al-'Arabiyah, 2004.

Esack, Farid. The Qur'an: A Short Introduction. Oxford: Oneworld, 2002.

Fahcrodin, Aziz Anwar. The Islamic State in Ira and Al-Sham (ISIS): Anatomy of Theology and Justifications of Violence. Yogyakarta: Center for Religious and Cross-Cultural Studies, 2016.

Hardiman, F. Budi. Seni Memahami Hermeneutik dari Schleiemacher sampai Derrida. Yogyakarta: Kanisius, 2015.

Haykal, Muhammad Husayn. Hayāt Muhammad. Cairo: al-Hay'ah al-Mișriyyah al-'Ammah li al-Kitab, 2001.

al-Sibā'ī, Musțafā. Al-Sīrah al-Nabawiyyah Durūs wa 'Ibar. Cairo: Dār al-Salām, 1998.

al-Ṭabāțabā'î, Sayyid Muḥammad Ḥusayn. Al-Mìzān fì Tafsìr alQur'ān. Beirut: Mu'āssasah al-A'lā, 1991.

Ibn Hishām, 'Abd al-Mālik. Al-Sìrah al-Nabawiyyah. Cairo: Dār alHadīth, 1998.

Ibn Kathīr, Al-Imām Abū al-Fidā' Ismā'īl ibn 'Umar. Tafsīr alQur'ān al-Ažìm. Beirut: Dār al-Kutub al-'Ilmiyah, 1998.

Imrān, 'Abdurrahmān Ḥamd 'Alī. Dìn al-Haqq. KSA: Ministry of Islamic Affairs, 1998.

Leeuw, G. van der. Religion in Essence and Manifestation. Princeton: Princeton University Press, 1986.

Levine, Stewart. Getting to Resolution: Turning Conflict into Collaboration. California: Berret-Koehler Publisher, 2009.

Locke, John. Two Treaties of Government. Cambridge: Cambridge University Press, 1960.

Mustofa, Imron. "Kritik Metode Kontekstualisasi Penafsiran AlQur'an Abdullah Saeed." ISLAMICA: Jurnal Studi Keislaman 10, no. 2 (March 2016): 465-491.

Naf'atu, Lien Iffa. “Interpretasi Kontestual Abdullah Saed: Sebuah Penyempurnaan Terhadap Gagasan Tafsir Fazlur Rahman." Hermeneutik 9, no. 1 (June 2015): 65-90. 
Rahman, Fazlur. Islam and Modernity: Transformation of an Intellectual Tradition. Chicago: University of Chicago Press, 1984.

- - - Major Themes of the Qur'an. Chicago: Bibliotheca Islamica, 1994.

Saeed, Abdullah. Interpreting the Qur'an: Towards a Contemporary Approach. New York: Routledge, 2006.

- - - Introduction to the Qur'an: History, Interpretation and Approaches. New York: Routledge, 2008.

---. Reading the Qur'an in the Twenty-First Century: A Contextualist Approach. New York: Routledge, 2014.

Saeed, Abdullah, and Ali Akbar. "Interpretation and Mutability: Socio-Legal Texts of the Quran; Three Accounts from Contemporary Iran." Middle Eastern Studies 54, no. 3 (May 2018): 442-458.

Sahiron, Syamsuddin. "A Peaceful Message beyond the Permission of Warfare (Jihad)"." In (Un)Common Sounds: Song of Peace and Reconciliation among Muslims and Christians, by Roberta N King and Sooi Ling Tan. Oregon: Cascade Books, 2014.

Shahbah, Muḥammad Abū. Al-Madkhal li Dirāsāt al-Qur'ān. RiyadKSA: Dār al-Liwā, 1987.

Smith, Wilfred Cantwell. What Is Scripture: A Comparative Approach. Minneapolis: Fortress Press, 1993.

Zartman, I William. Negotiation and Conflict Management. New York: Routledge, 2008. 